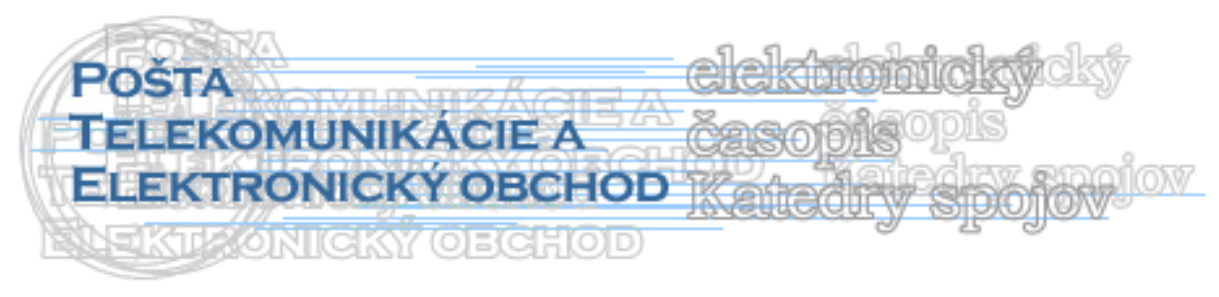

\title{
INVESTIČNÉ RIZIKO
}

\section{Lucia Tokarčíková*}

Problematika rizika je dôležitou súčast’ou vedomostí investora. Pojem riziko sa definuje napríklad ako ,zdroj nebezpečenstva alebo možnosti spôsobenia straty alebo nešt'astia"“1.

Riziko vo financiách môžeme definovat' ako 'kvantifikovatel'nú pravdepodobnost' straty alebo nižších ako očakávaných príjmov““2 .

Táto definícia nie je celkom presná, lebo zohl'adňuje len jeden z dvoch zásadných rozdielov oproti pojmu všeobecného rizika a to jeho kvanfikovatel'nost'.

Vo financiách tomu tak nie je, pretože investičné riziko, najmä portfóliové riziko, znamená nielen možnost' straty ale aj rovnakú možnost' zisku. Aj pri investíciách do cenných papierov existujú výnimky. $\mathrm{V}$ tejto súvislosti preto rozlišujeme:

a) symetrický rizikový profil - znamená, že riziko v tomto prípade predstavuje rovnako pravdepodobnost' straty ako aj výnosu. Takýto rizikový profil môžeme pozorovat' najmä pri akcií, ale aj pri niektorých finančných derivátoch;

b) asymetrický rizikový profil - znamená pravdepodobnost' pohybu očakávaných výnosov len jedným smerom. Takéto obmedzenie rizika je pozorovatel'né len u opcií, pretože predstavujú právo uplatnit' ich, ale nie povinnost'.

Vel'kost' investičného rizika môžeme merat' práve hodnotou rozptylu $\sigma^{2}(\mathrm{r})$ alebo štandardnej odchýlky $\sigma(r)$ náhodnej hodnoty výnosu „r“;

$$
\sigma_{(r)}^{2}=\sum_{k=1}^{n} p_{k}\left(r_{k}-E_{(r)}\right)^{2}
$$

kde $\quad \mathrm{p}_{\mathrm{k}}$ - pravdepodobnost' $\mathrm{k}$-tého výnosu aktíva, $\mathrm{k}=1,2, \ldots \ldots \mathrm{n}$

$\mathrm{r}_{\mathrm{k}}$ - k-tý výnos aktíva, $\mathrm{k}=1,2, \ldots \ldots . \mathrm{n}$

$\mathrm{E}(\mathrm{r})$ - očakávaný výnos aktíva.

\footnotetext{
* Ing. Lucia Tokarčíková, Katedra spojov, Fakulta prevádzky a ekonomiky dopravy a spojov, Žilinská univerzita v Žiline, Univerzitná 1, 01026 Žilina, Slovenská republika

1 SHARPE, W. F. - ALEXANDER, G. J.: Investice, Praha, Victoria Publishing, 1994, ISBN 80-85605-47-3

${ }^{2}$ BLAKE, D.: Analýza finančních trhu, Praha, Grada, 1995, ISBN 80-7169-201-8
} 
Investičné riziko možno rozdelit’ na dve základné zložky:

1. špecifické riziko

2. trhové riziko (systematické riziko)

1. Špecifické riziko sa nazýva vodbornej literatúre aj nesystematické, premenlivé, diverzifikovatel'né ${ }^{3}$ alebo jedinečné riziko. Pokial' sú výnosy aktív ovplyvňované faktormi, ktoré majú charakter špecifických javov podnikov, potom faktory nazývame nesystematickým rizikom. Príkladom môže byt' podnikatel'ské alebo finančné riziko. Táto skupina rizík vyplýva priamo z hospodárenia a činnosti eminentov jednotlivých aktív:

- podnikatel'ské riziko - je spojené s dôsledkom špecifických problémov jednotlivých odvetví alebo podnikov;

- finančné riziko - je spojené s využívaním cudzieho kapitálu pri financovaní podnikatel'kých aktivít. Čím väčšia čast' aktív je financovaná cudzím kapitálom, tým väčšie je finančné riziko takéhoto podniku.

Podl’a Blakea sa špecifické riziko skladá z nasledovných druhov:

a) Manažérske riziko - je najväčšie pri nových alebo neznámych firmách, ktoré môžu mat' problém presadit' sa na finančných trhoch;

b) Operačné riziko - predstavuje riziko, že firma nebude schopná generovat' dostatočné tržby na krytie fixných nákladov jej činnosti. Týka sa aktívnej strany súvahy firmy;

c) Finančné riziko - týka sa pasívnej strany súvahy firmy a je to riziko, že firma nebude schopná kryt’ fixné náklady, ako sú napríklad fixné úrokové náklady;

d) Zálohové riziko - je závislé od toho, aké má investor požiadavky na aktíva firmy, ktorá sa ocitla v konkurze. Vo všeobecnosti to znamená poradie, ktorom sa budú uspokojovat' investori. Investori sa uspokojujú v nasledovnom poradí podl'a typu investície: zaistené dlhopisy, nezaistené dlhopisy, preferenčné akcie a nakoniec kmeňové akcie.

Všetky druhy špecifického rizika môžeme z matematického (štatistického) hl'adiska nazvat' aj variačným rizikom.

2. Trhové riziko môžeme ho nazvat' systematickým rizikom. Vyznačuje sa hlavne tým, že ho nemožno diverzifikovat'. Zatial' čo špecifické riziko vyplýva z konkrétnej situácie v konkrétnej firme, trhové riziko je ovplyvňované makroekonomickými udalost'ami. Výkonnost' trhu je ovplyvňovaná čisto len makroekonomickými podmienkami, pretože špecifické /mikroekonomické/ podmienky sa na trhu sa spriemerujú pôsobením tisícov firiem a cenných papierov a tým nemajú na trhovú výkonnost' žiaden vplyv. Zatial' čo špecifické riziko straty solventnosti firmy, trhové riziko väčšinou ovplyvňuje len cenu cenného papiera emitovaného firmou na trhu.

\footnotetext{
${ }^{3}$ Diverzifikáciou rozumieme proces pridávania akcií do portfólia za účelom zníženia špecifického rizika. Č́́m väčší počet akcií portfólio obsahuje, tým nižšie je jeho špecifické riziko, teda aj jeho celkové riziko.
} 
Najdôležitejšie prvky systematického rizika sú tieto:

- riziko zmeny úrokových sadzieb,

- trhové riziko,

- inflačné riziko.

a/ Úrokové riziko - ovplyvňuje kolísanie výnosov aktív tým, že sa mení hladina úrokových mier. Tieto zmeny inverzne ovplyvňujú ceny aktív, t. j. pri raste úrokových mier pri ináč nezmenených podmienkach ceny aktív klesajú;

b/ Trhové riziko - ovplyvňuje kolísanie výnosov aktív v dôsledku kolísania trhu ako takého. Trhovému riziku sú vystavené všetky aktíva, hoci primárne ovplyvňuje ceny akcií. Samotné trhové riziko je výsledkom pôsobenia vel'kého množstva exogénnych faktorov medzi, ktoré patrí predovšetkým očakávanie recesie, štrukturálne zmeny v ekonomike, zmeny spotrebitel'ských preferencií a politické šoky;

c/ Inflačné riziko - ovplyvňuje reálny výnos jednotlivých aktív, pričom vysoká inflácia môže mat' dokonca za následok záporné miery výnosu.

Pretože systematické riziko sa nedá diverzifikovat', požadujú zaň investori rizikovú prémiu. Túto prémiu väčšinou zarátajú spolu s reálnym úrokom, infláciou a prémiou za likviditu do nominálnej úrokovej miery, ktorej výpočet ilustruje známy vzt’ah:

$$
r=\rho+\pi+1+\sigma
$$

kde $\quad \mathrm{r}$ - nominálna úroková miera

$\rho$ - reálna úroková miera

$\pi$ - očakávaná miera inflácie

1 - prémia za likviditu

$\sigma$ - prémia za trhové riziko

A grafické znázornenie je zrejmé z nasledovného obrázku č. 1.

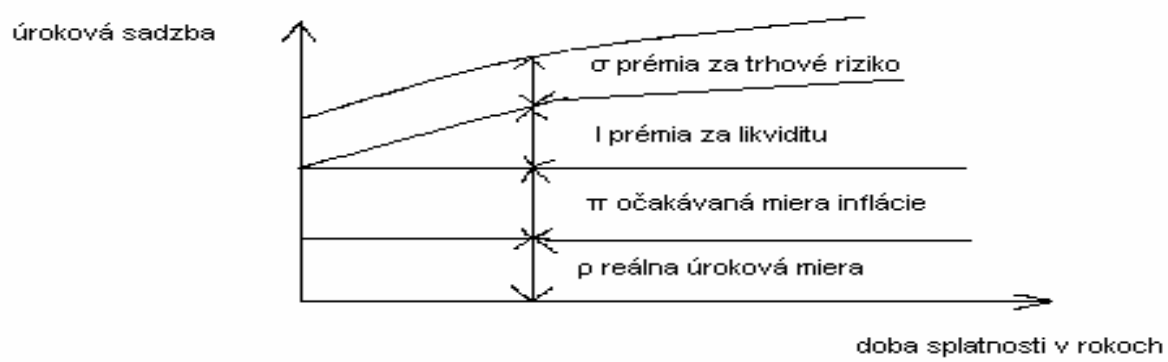

Obrázok č. 1 Dekompozícia výnosovej krivky

Výnosová krivka na obrázku č. 1 je rozložená na jednotlivé zložky podl’a uvedeného vzt'ahu (1.2). Vidíme, že čím dlhšia je doba splatnosti alebo doba držania, tým požadujú 
investori vyššiu prémiu za likviditu a riziko. Platí tu zákon klesajúceho hraničného prírastku k požadovanej prémii. Systematické riziko matematicky môžeme nazvat' aj kovariančným.

\section{Literatúra}

[1] BLAKE, D.: Analýza finančních trhu, Praha, Grada, 1995, ISBN 80-7169-201-8

[2] SHARPE, W. F. - ALEXANDER, G. J.: Investice, Praha, Victoria Publishing, 1994, ISBN 80-85605-47-3 